\title{
The Mechanism of Salt Wastage in Chronic Renal Disease*
}

\author{
Alan J. Coleman, $\dagger$ Manuel Arias, $\dagger$ Norman W. Carter, Floyd C. Rector, Jr., \\ and Donald W. Seldin $\ddagger$ \\ (From the Department of Internal Medicine, The University of Texas Southwestern \\ Medical School, Dallas, Texas)
}

It is well known that patients with chronic renal disease have an impaired ability to conserve sodium (1-7). In a small number of patients this results in profound salt wasting (8-13), but more commonly the defect is mild and becomes apparent only during severe sodium deprivation. The cause of this inability to conserve sodium maximally has not been characterized. The studies reported here were designed to examine mild salt wastage in a group of patients with chronic renal failure.

During severe salt restriction, a normal individual can lower urinary sodium concentration nearly to zero. The final and near total extraction of sodium from tubular fluid is known to occur in the distal nephron (14). In the circumstance of nephron overperfusion resulting from renal disease $(15,16)$, the failure to reabsorb sodium maximally during sodium deprivation might be the consequence of the inability of the distal nephron either to increase its reabsorptive capacity proportionate to the increased loads delivered to it or to generate maximal concentration gradients of sodium between tubular fluid and blood.

In the present studies these two possibilities were examined by measuring the effect on sodium excretion of variations in urine flow during water diuresis. Water diuresis is assumed to increase flow in the distal nephron without augmenting so-

\footnotetext{
* Submitted for publication August 26, 1965; accepted March 21, 1966.

This work was supported in part by training grants 5-TI-HE-5469-05 and HTS-5469-C3 from the National Institutes of Health.

Presented in part at the Annual Meeting of the American Federation for Clinical Research, Atlantic City, N. J., May 1964.

† Work performed as a trainee of the U. S. Public Health Service under grants 5-TI-HE-5469-05 and HTS5469-C3.

$\ddagger$ Address requests for reprints to Dr. Donald W. Seldin, Dept. of Internal Medicine, The University of Texas Southwestern Medical School, 5323 Harry Hines Blvd., Dallas, Texas 75235.
}

dium delivery. Consequently, if salt wastage resulted from an inadequate capacity of the distal nephron to reabsorb sodium, the concentration of urinary sodium would fall as urine flow mounted, and, therefore, sodium excretion would remain unchanged. On the other hand, if sodium reabsorption were limited by an inability to lower the concentration of sodium in distal tubular fluid below a relatively high fixed minimal value, the concentration of sodium would remain unchanged as flow increased; therefore, the excretion of sodium would rise.

The results of our studies indicate that the salt wasting of renal disease results from an inability of the distal nephron to generate maximal concentration gradients between tubular fluid and blood.

\section{Methods}

The studies were performed on a group of 17 patients with advanced chronic renal disease. Glomerular filtration rates, measured by endogenous creatinine clearance, ranged from 3 to $20 \mathrm{ml}$ per minute. The diagnoses in these patients, determined by standard clinical criteria and confirmed by autopsy in 7 of the patients, were: arteriolar nephrosclerosis (12 patients), chronic glomerulonephritis (2 patients), chronic pyelonephritis (1 patient), diabetic glomerulosclerosis with chronic pyelonephritis (1 patient), and polycystic kidney disease (1 patient). All patients were hospitalized on a metabolic ward during the study. None of these patients wasted salt while on ad libitum sodium intake before the study. At the time of these studies, none of the patients had any clinical evidence of uremia, congestive heart failure, or edema, nor were they receiving diuretic agents.

Four separate studies were performed:

1) The balance of sodium during salt restriction. Fourteen subjects were placed on a diet containing 10 to $15 \mathrm{mEq}$ of sodium per day. Fluid intake was maintained at 1,500 to $2,000 \mathrm{ml}$ per day. Daily weights and 24-hour urine samples were collected; plasma and urinary electrolyte composition was determined; creatinine clearance was measured.

When sodium excretion had fallen to the lowest level that each subject could attain and stabilized at this level for 3 days, the following studies were performed: 
2) Changes in 24-hour urinary sodium excretion induced by raising fluid intake ( 8 patients). Fluid intake was increased from $2 \mathrm{~L}$ per day to 3 or $4 \mathrm{~L}$ per day, without varying sodium intake.

3) Changes in sodium excretion induced by acute water loading (11 patients). Water diuresis was induced by drinking $1 \mathrm{~L}$ of water in 30 minutes. Urine was then collected for measurement of sodium at 30 -minute intervals for the next 2 to 3 hours, or until urine flow was maximal. In most instances potassium excretion and endogenous creatinine clearance were also determined. These studies were performed during the morning, while the subjects were fasting and recumbent.

In three of these studies the effect on sodium excretion of glomerular underperfusion, induced by hypotension, was examined. Water diuresis was first established; when a maximal urine flow was obtained, blood pressure was lowered by ganglionic blockade with an infusion of trimethaphan in conjunction with elevation of the head of the bed. A fall in blood pressure of approximately $50 \%$ was achieved and maintained for 2 hours. Urine collections were continued at 30 -minute intervals during the period of hypotension.

In 4 patients in the salt-depleted state, acute water loading was repeated after the administration of $1 \mathrm{mg}$ $9 \alpha$-fluorohydrocortisone, given orally in divided doses over a 12 -hour period.

4) Changes in sodium excretion induced by acute water loading after correction of the sodium deficit (9 patients). After completion of the studies of sodium excretion during salt deprivation, 6 patients were placed on supplementary sodium chloride, $5 \mathrm{~g}$ per day, until sodium excretion had stabilized at about the level of intake. The acute water loading study was then repeated. Three other patients with chronic renal disease who had not been subject to sodium deprivation were included in this group.

In addition, the pattern of urinary sodium excretion during water diuresis was examined in a group of 5 normal subjects, both during sodium deprivation and again during normal salt intake. In 4 more normal subjects who had been salt deprived, water diuresis was superimposed on a stable osmotic diuresis. Five per cent mannitol was infused at $5 \mathrm{ml}$ per minute; when osmolar clearance became constant, the water loading study was repeated.

In all studies, determinations of sodium and potassium were done by flame photometry, and creatinine by the method of Bonsnes and Taussky as modified for the Technicon autoanalyzer.

\section{Results \\ I) Studies on patients with chronic renal disease \\ Pertinent data from all the balance studies are summarized in Table I. In all 14 patients re- striction of dietary sodium to 10 to $15 \mathrm{mEq}$ per day resulted in a slow fall in urinary sodium excre- tion $\left(\mathrm{U}_{\mathrm{Na}} \mathrm{V}\right)$ over approximately 2 weeks to 12 to $20 \mathrm{mEq}$ per day, where excretion stabilized. Since}

water intake was maintained constant at 1,500 to $2,000 \mathrm{ml}$ daily, urine volume did not vary markedly. The concentration and excretion of urinary sodium tended to fall to their minimal values simultaneously. In only two instances (P.E., J.R.) was the concentration of urinary sodium $\left(U_{N a}\right)$ reduced below $10 \mathrm{mEq}$ per $\mathrm{L}$. Ten of 14 patients persisted in negative salt balance at the end of the balance period. In one instance (R.J.), despite a loss of $661 \mathrm{mEq}$ of sodium in 11 days, the patient was still wasting $20 \mathrm{mEq}$ sodium daily into the urine. In no instance was the daily $\mathrm{U}_{\mathrm{Na}} \mathrm{V}$ reduced below $12 \mathrm{mEq}$ despite markedly negative sodium balances.

The concentration of serum sodium fell in 13 of 14 patients. In the case of E.R. the serum sodium concentration fell $21 \mathrm{mEq}$ per $\mathrm{L}$ to $114 \mathrm{mEq}$ per L. Water retention tended partially to mask the weight loss anticipated from the magnitude of the negative sodium balance, so that in certain instances a negative sodium balance was not associated with weight loss. In every case where creatinine clearance was measured (11 of 14), the clearance fell after the period of salt restriction.

In Figure 1 the balance data from a representative patient (R.W.) are plotted. It is apparent that this patient could not reduce $\mathrm{U}_{\mathrm{Na}}$ below 20 $\mathrm{mEq}$ per $\mathrm{L}$. Since urine volume never fell below $700 \mathrm{ml}$ per day, the patient was persistently in negative balance after 23 days of sodium restriction. When sodium intake was abruptly increased by $30 \mathrm{mEq}$ per day, the increment of salt was almost completely retained so that $\mathrm{U}_{\mathrm{Na}}$ and $\mathrm{U}_{\mathrm{Na}} \mathrm{V}$ were not appreciably altered as the sodium deficit was replenished.

After $\mathrm{U}_{\mathrm{Na}}$ and $\mathrm{U}_{\mathrm{Na}} \mathrm{V}$ had stabilized at the minimal values, 3 patients (T.D., J.R., and E.L.) were given $0.1 \mathrm{mg} 9 \alpha$-fluorohydrocortisone daily, and the balance study was continued for an additional 3 days. The administration of $9 \alpha$-fluorohydrocortisone had no effect on either $U_{\mathrm{Na}}$ or $\mathrm{U}_{\mathrm{Na}} \mathrm{V}$ in any of the 3 patients.

Changes in 24-hour urinary sodium excretion induced by raising fluid intake. Fluid intake was held constant at 1.5 to $2 \mathrm{~L}$ per day during the period of sodium deprivation; consequently, daily urine volume was also fairly constant for each patient. In 7 patients, after $\mathrm{U}_{\mathrm{Na}} \mathrm{V}$ had fallen and stabilized at its lowest level, fluid intake was abruptly raised to $2.5 \mathrm{~L}$ per day; in an eighth pa- 
COLEMAN, ARIAS, CARTER, RECTOR, AND SELDIN

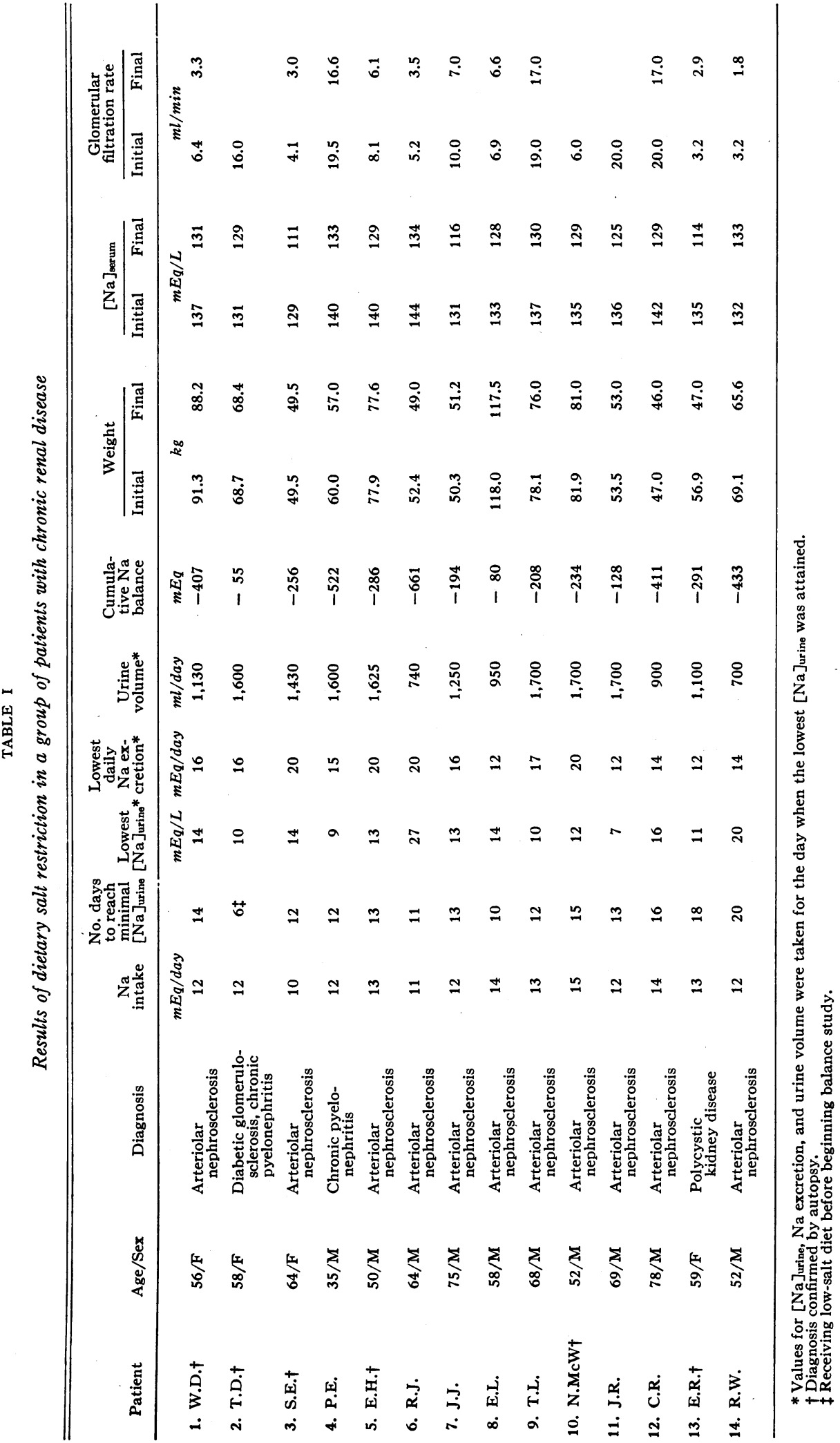




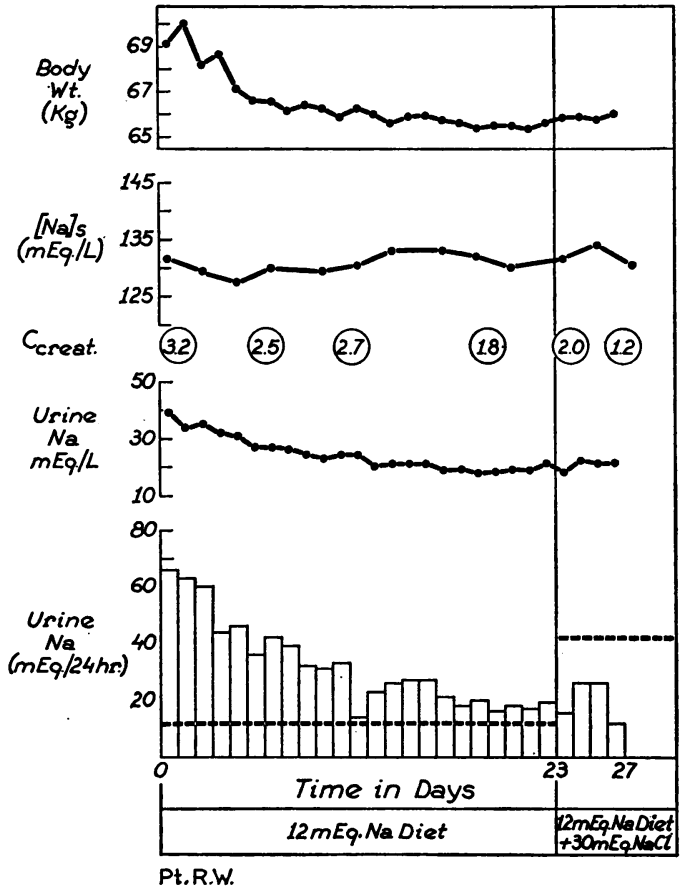

Fig. 1. EFFECT OF SODIUM RESTRICTION AND REPLETION ON PLASMA AND URINARY SODIUM DURING A 27-DAY BALANCE PERIOD IN A PATIENT WITH CHRONIC RENAL DISEASE. The horizontal dashed line in the lowest panel represents the level of sodium intake. $[\mathrm{Na}]_{1}=$ concentration of sodium in serum; $C_{\text {ereat. }}=$ creatinine clearance.

tient fluid intake was raised from 2.5 to $4 \mathrm{~L}$ per day. Urine volume increased substantially in all subjects from a mean value of 1,160 to 2,110 per day, but $U_{\mathrm{Na}}$ was unchanged. Therefore, total 24-hour $\mathrm{U}_{\mathrm{Na}} \mathrm{V}$ rose in direct proportion to the increase in urine volume. Figure 2 illustrates the response of $\mathrm{U}_{\mathrm{Na}} \mathrm{V}$ to an increase in urine volume in a typical salt-depleted patient.

Change in sodium excretion induced by acute water loading. To examine the apparent flow dependence of $\mathrm{U}_{\mathrm{Na}} \mathrm{V}$ in the salt-depleted state more closely, we induced acute water diuresis as described in 11 patients. Because of the marked impairment of renal function in all of these patients, urine flow increased only modestly in response to a standard water load. Nevertheless, increments in urine flow of at least $100 \%$ were achieved by nearly all patients during the 3 -hour period of study.

Figure 3 illustrates the typical effects on urinary sodium of an acute increase in urine flow induced by water diuresis. Urine flow increased from 1.3 to $3.1 \mathrm{ml}$ per minute, but $\mathrm{U}_{\mathrm{Na}}$ remained

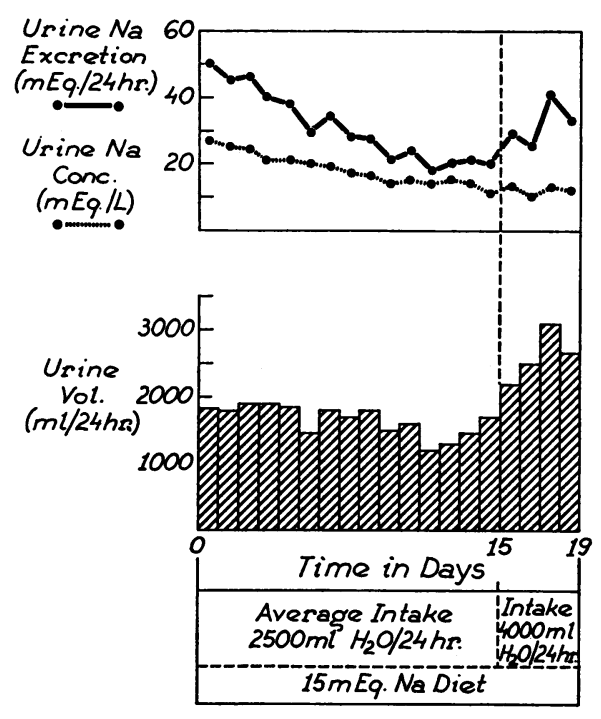

Fig. 2. EFfect of increasing the water intake DURING SALT RESTRICTION ON URINARY CONCENTRATION AND EXCRETION OF SODIUM IN A PATIENT WITH CHRONIC RENAL DISEASE.

essentially unchanged: In consequence, $\mathrm{U}_{\mathrm{Na}} \mathrm{V}$ increased in almost direct proportion to urine flow. ${ }^{1}$
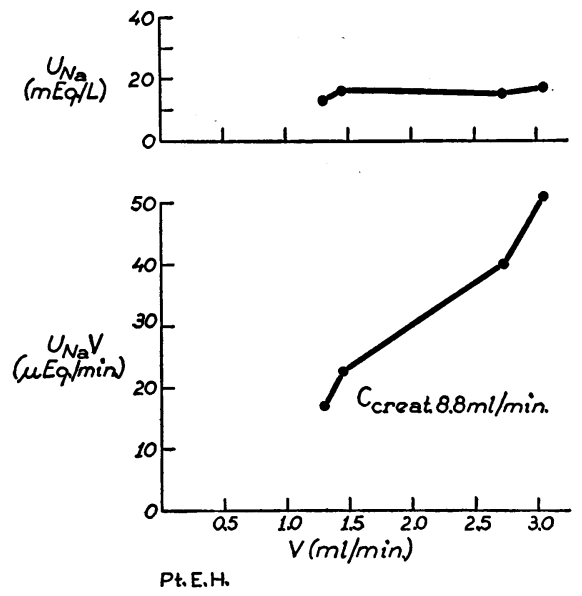

Fig. 3. EFFECT OF AN ACUTE WATER LOAD ON URINARY CONCENTRATION ( $U_{\mathrm{Na}}$ ) AND EXCRETION $\left(\mathrm{U}_{\mathrm{Na}} \mathrm{V}\right.$ ) IN A PATIENT WITH CHRONIC RENAL DISEASE DURING SALT RESTRICTION. Urinary sodium concentration is fixed at the relatively high level of $18 \mathrm{mEq}$ per $\mathrm{L}$. An approximate threefold increase in urine flow (V) elicits an approximate threefold increase in sodium excretion.

${ }^{1} \mathrm{By}$ a "proportionate" increase in $\mathrm{U}_{\mathrm{Na}} \mathrm{V}$ with urine flow, we mean that the percentage increase in flow elicits the identical percentage increase in $\mathrm{U}_{\mathrm{Na}} \mathrm{V}$. This defines "complete" flow dependence. If the percentage increase in $\mathrm{U}_{\mathrm{Na}} \mathrm{V}$ is less than the percentage increase in urine flow, $\mathrm{U}_{\mathrm{Na}} \mathrm{V}$ is termed "partially" flow dependent. 

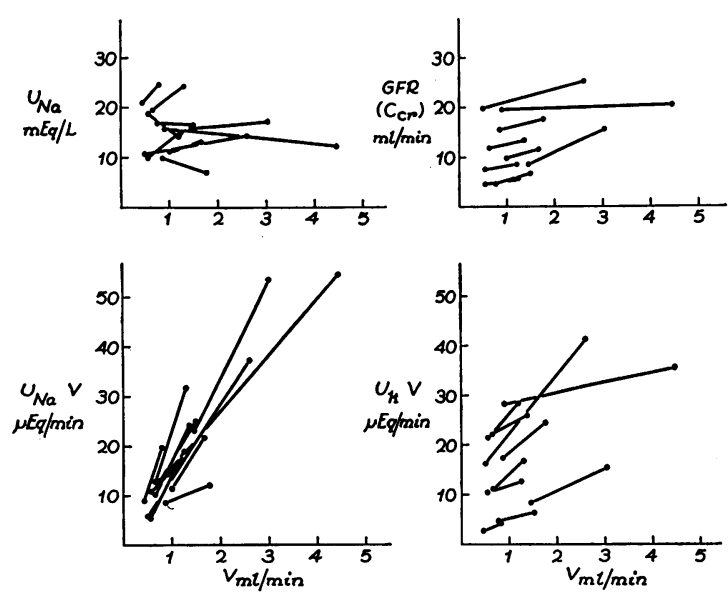

Fig. 4. EFfects of an acUte Water LOAD DURING SALT DEPRIVATION ON URINARY SODIUM AND POTASSIUM AND CREATININE CLEARANCE IN THE GROUP OF PATIENTS WITH CHRONIC RENAL DISEASE. GFR = glomerular filtration rate.

In Figure 4 the effect of a water load on the urinary excretion of sodium and potassium and on glomerular filtration rate (GFR) is plotted for the group as a whole. Only the values associated with the minimal and maximal urine flow are charted (we omitted charting intermediate points because of the clutter that resulted). $U_{\mathrm{Na}}$ fell slightly in 3 patients, rose slightly in 4 , and remained unchanged in 4. In all patients $\mathrm{U}_{\mathrm{Na}} \mathrm{V}$ rose in almost direct proportion to urine flow, $\mathrm{U}_{\mathrm{Na}} \mathrm{V}$ increasing

TABLE II

Effect of $9 \alpha$-fluorohydrocortisone on urinary sodium concentration at low and high flows during administration of water

\begin{tabular}{|c|c|c|c|c|}
\hline \multirow[b]{2}{*}{ Patient and treatment } & \multicolumn{2}{|c|}{ Antidiuresis } & \multicolumn{2}{|c|}{$\begin{array}{c}\begin{array}{c}\text { Maximal } \\
\text { water diuresis }\end{array} \\
\end{array}$} \\
\hline & $\mathrm{UNa}_{\mathrm{Na}} *$ & $\mathrm{UNaV}^{*}$ & $\mathrm{U}_{\mathrm{Na}}$ & $\mathrm{UNa}_{\mathrm{Na}}$ \\
\hline & $m E q / L$ & $\underset{\min }{\mu E q /}$ & $m E q / L$ & $\underset{\min }{\mu E q /}$ \\
\hline $\begin{array}{l}\text { 1. J.C. } \\
\text { Before } 9 \alpha \text {-fluoro. } \\
\text { After } 9 \alpha \text {-fluoro. } \dagger\end{array}$ & $\begin{array}{r}10.0 \\
6.0\end{array}$ & $\begin{array}{l}5.5 \\
2.7\end{array}$ & $\begin{array}{l}15.5 \\
12.3\end{array}$ & $\begin{array}{l}19.0 \\
23.4\end{array}$ \\
\hline $\begin{array}{l}\text { 2. W.D. } \\
\text { Before } 9 \alpha \text {-fluoro. } \\
\text { After } 9 \alpha \text {-fluoro. } \dagger\end{array}$ & $\begin{array}{l}16.7 \\
13.9\end{array}$ & $\begin{array}{l}13.9 \\
12.9\end{array}$ & $\begin{array}{l}16.7 \\
14.7\end{array}$ & $\begin{array}{l}25.1 \\
26.5\end{array}$ \\
\hline $\begin{array}{l}\text { 3. T.D. } \\
\text { Before } 9 \alpha \text {-fluoro. } \\
\text { After } 9 \alpha \text {-fluoro. } \dagger\end{array}$ & $\begin{array}{l}7.5 \\
6.0\end{array}$ & $\begin{array}{r}5.5 \\
11.5\end{array}$ & $\begin{array}{l}6.8 \\
7.1\end{array}$ & $\begin{array}{l}12.0 \\
16.2\end{array}$ \\
\hline $\begin{array}{l}\text { 4. F.L. } \\
\text { Before } 9 \alpha \text {-fluoro. } \\
\text { After } 9 \alpha \text {-fluoro. } \dagger\end{array}$ & $\begin{array}{l}18.7 \\
12.4\end{array}$ & $\begin{array}{l}10.8 \\
15.9\end{array}$ & $\begin{array}{l}10.0 \\
16.7\end{array}$ & $\begin{array}{r}8.7 \\
33.4\end{array}$ \\
\hline
\end{tabular}

* $\mathrm{U}_{\mathrm{Na}}=$ urinary sodium concentration; $\mathrm{UNa}_{\mathrm{Na}}=$ urinary sodium excretion.

$+0.25 \mathrm{mg} 9 \alpha$-fluorohydrocortisone given orally every 3 hours for the 12 hours before study. an average of $154 \%$ as $\mathrm{V}$ increased an average of $151 \%$ for the group of 11 patients. The intermediate points for both $\mathrm{U}_{\mathrm{Na}}$ and $\mathrm{U}_{\mathrm{Na}} \mathrm{V}$ fell along the lines connecting the minimal and maximal values.

Urinary potassium excretion $\left(\mathrm{U}_{\mathbf{K}} \mathrm{V}\right)$ was measured in 10 of these studies. In all instances $U_{K} V$ rose as urine flow mounted, but the rate of rise was small compared with that of sodium (Figure 4, lower right panel).

Changes in glomerular filtration rate during the acute study were recorded in 9 patients by measurement of endogenous creatinine clearance $\left(\mathrm{C}_{\mathrm{Cr}}\right)$ during each of the 30 -minute collection periods. There seemed to be a trend for the GFR to rise slightly with water loading, as summarized in Figure 4, which includes only those $\mathrm{C}_{\mathrm{Cr}}$ at the minimal and maximal urine flows. However, the $\mathrm{C}_{\mathrm{Cr}}$ were quite erratic when the intermediate periods were considered. In only 2 of 9 instances was there a persistent rise in $\mathrm{C}_{\mathrm{Cr}}$ with urine flow.

To determine whether the kidney in renal failure fails to reduce $U_{\mathrm{Na}}$ and $\mathrm{U}_{\mathrm{Na}} \mathrm{V}$ optimally owing

TABLE III

Effect of hypotension on urinary sodium concentration in salt-deprived patients with renal disease

\begin{tabular}{ccccc}
\hline \hline Patient & Period & $\mathrm{Ccr} *$ & $\mathrm{~V}^{*}$ & $\mathrm{U}_{\mathrm{Na}} *$ \\
\hline & & $\operatorname{ml} / \mathrm{min}$ & $\operatorname{ml} / \min$ & $m E q / L$ \\
1. E.H. & $1)$ & 19.5 & 0.90 & 15.8 \\
& $2)$ & 27.5 & 1.9 & 15.5 \\
& $3)$ & 18.6 & 2.8 & 10.7 \\
& $4)$ & 20.3 & 4.5 & 12.2
\end{tabular}

Trimethaphan infusion started

$\begin{array}{lrrr}5) & 10.8 & 0.75 & 7.4 \\ 6) & 13.3 & 1.00 & 6.8 \\ 7) & 9.7 & 0.55 & 6.8 \\ 8) & 10.3 & 0.50 & 7.6 \\ 1) & 19.8 & 0.50 & 10.8 \\ 2) & 25.0 & 2.60 & 14.3 \\ 3) & 21.0 & 2.07 & 8.5 \\ 4) & 22.2 & 2.33 & 9.0\end{array}$

Trimethaphan infusion started

$\begin{array}{llll}5) & 13.0 & 0.67 & 6.3\end{array}$

$\begin{array}{llll}5) & 13.0 & 0.67 & 6.3 \\ 6 & 14.1 & 0.40 & 5.8\end{array}$

$\begin{array}{llll}6) & 14.1 & 0.40 & 5.8 \\ 7) & 11.1 & 0.70 & 6.5\end{array}$

$\begin{array}{rrrr}7) & 11.1 & 0.70 & 6.5 \\ 8) & 9.3 & 0.33 & 8.3\end{array}$

$\begin{array}{lllll}\text { 3. J.J. } & \text { 1) } & 11.5 & 0.9 & 8.0\end{array}$

Trimethaphan infusion started

$\begin{array}{llll}3) & 6.1 & 0.3 & 7.0 \\ 4) & 5.9 & 0.3 & 6.8 \\ 5) & 5.7 & 0.3 & 6.5\end{array}$

$* \mathrm{C}_{\mathrm{r}}=$ creatinine clearance $; \mathrm{V}=$ urine flow; $\mathrm{U}_{\mathrm{Na}}=$ urinary sodium concentration. 

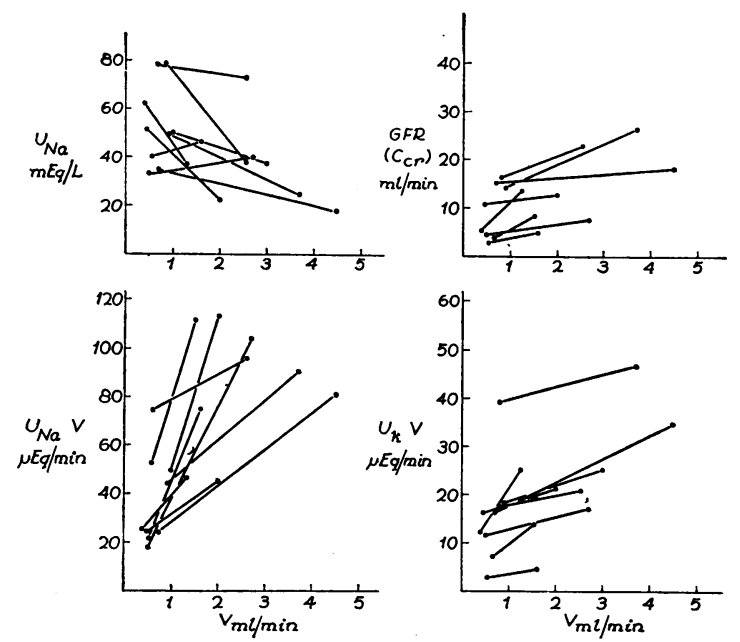

Fig. 5. EFFect of AN ACUTE WATER LOAD DURING PERIODS OF ADEQUATE DIETARY SALT ON URINARY SODIUM AND POTASSIUM AND CREATININE CLEARANCE IN THE GROUP OF PATIENTS WITH CHRONIC RENAL DISEASE.

to inadequate mineralocorticoid excretion, we examined the influence of $9 \alpha$-fluorohydrocortisone. It is apparent from Table II that the hormone produced no consistent effects during either antidiuresis or water diuresis.

The relatively high minimal $U_{\mathrm{Na}}$ (about $10 \mathrm{mEq}$ per L, Figure 4) might be the expression in some manner of either nephron damage or overperfusion. GFR was therefore lowered by inducing hypotension with ganglionic blockade during water diuresis in 3 patients (Table III). It is apparent that with the sharp fall in GFR, $U_{\mathrm{Na}}$ could be significantly depressed despite a marked reduction in urine flow.

Changes in sodium excretion induced by acute water loading after correction of the sodium deficit. In 6 patients salt repletion was accomplished by adding $5 \mathrm{~g}$ of sodium chloride per day to the basic diet, which was otherwise unchanged. Three other patients with renal disease who had not been subject to sodium depletion were also studied. In contrast to the relatively stable $U_{\mathrm{Na}}$ when urine flow was increased during salt restriction $\left(\mathrm{U}_{\mathrm{Na}}\right.$ increased $\left.7 \pm 8 \% \mathrm{SE}\right), \mathrm{U}_{\mathrm{Na}}$ fell as flow increased in 7 of the 9 patients receiving salt (Figure $5 ; \mathrm{U}_{\mathrm{Na}}$ decreased $25 \pm 10 \% \mathrm{SE}$ ). The differences between the two groups had a $p$ value of $<0.02$. In the only 2 patients whose $U_{\mathrm{Na}}$ rose as flow increased, the glomerular filtration rate was the lowest of the group (Figure 5). In the re- maining 7 patients the average fall of $25 \%$ in $\mathrm{U}_{\mathrm{Na}}$ was small compared with the increase of approximately threefold in urine flow; therefore, $\mathrm{U}_{\mathrm{Na}} \mathrm{V}$ was partially flow dependent.

Potassium concentration $\left(U_{K}\right)$ fell as flow increased in all patients, but the decrease in concentration was not proportionate to the increase in flow: therefore $U_{\mathbf{K}} \mathrm{V}$ increased (Figure 5). The relative increase was small (mean increase, $29 \%$ ). Creatinine clearance also rose in all patients as flow mounted (Figure 5). The increments in $U_{K} V$ and creatinine clearance were nearly parallel and were small in comparison to the greater increase in $\mathrm{U}_{\mathrm{Na}} \mathrm{V}$.

\section{II) Studies on normal subjects}

Changes in sodium excretion with water diuresis during normal salt intake. $\mathrm{U}_{\mathrm{Na}}$ fell during water diuresis from very high levels before water loading to very low levels at the peak of urine flow. Sodium excretion bore no consistent relation to urine flow; in marked contrast to the response observed in patients with renal disease who were receiving salt, excretion showed essentially no change, even at extremely high flows (Figure 6).

Changes in sodium excretion with water diuresis during sodium restriction. During sodium restriction patients with renal disease reduced $\mathrm{U}_{\mathrm{Na}}$ to levels ranging from 7 to $27 \mathrm{mEq}$ per L despite a markedly negative sodium balance (Table I). In contrast, all 5 normal subjects on salt restric-
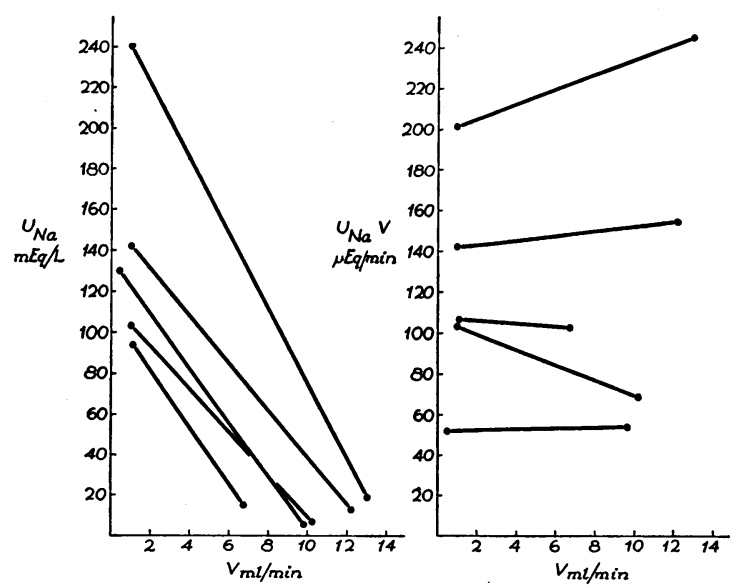

Fig. 6. EFFect OF AN ACUTE WATER LOAD DURING PERIODS OF ADEQUATE DIETARY SALT ON URINARY SODIUM IN THE GROUP OF NORMAL, SUBJECTS. 

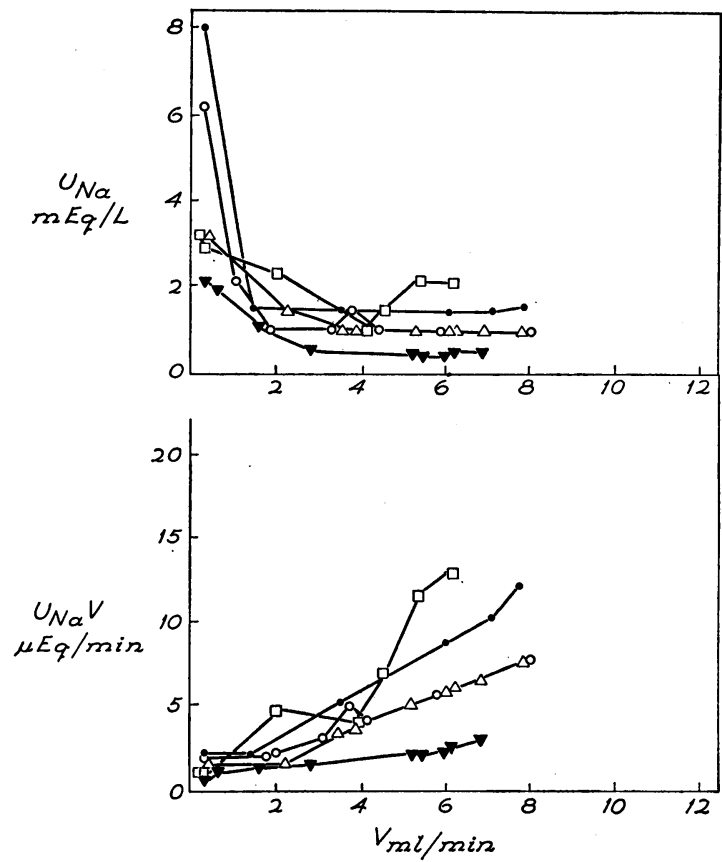

Fig. 7. EFFECT OF AN ACUTE WATER LOAD DURING SALt DEPRIVATION ON URINARY SODIUM IN THE GROUP OF NORMAL SUBJECTS. Note that when urine flow is about 2 to $3 \mathrm{ml}$ per minute, $U_{\mathrm{Na}}$ falls to a constant minimal value for each subject, and $U_{\mathrm{Na}} \mathrm{V}$, therefore, becomes completely flow dependent.

tion sharply lowered $\mathrm{U}_{\mathrm{Na}}$ to levels ranging from 2 to $8 \mathrm{mEq}$ per L during antidiuresis (Figure 7). During water diuresis in the normal subjects $U_{\mathrm{Na}}$ fell still further as urine flow increased to approximately $2 \mathrm{ml}$ per minute. As urine flow increased beyond this point, $U_{\mathrm{Na}}$ remained relatively constant at levels ranging from 0.5 to $2.0 \mathrm{mEq}$ per $\mathrm{L}$ in the different individuals. It is apparent that even a normal individual during salt restriction cannot reduce $U_{\mathrm{Na}}$ below a minimal value. When this floor is reached $\left(\mathrm{U}_{\mathrm{Na}}=0.5\right.$ to $2.0 \mathrm{mEq}$ per $\mathrm{L})$, further increases in urine flow are associated with proportionate increases in $\mathrm{U}_{\mathrm{Na}} \mathrm{V}$ (Figure 7).

Effect of water diuresis superimposed on a constant mannitol diuresis in 4 salt-depleted normal subjects. In all 4 normal subjects, the combination of water diuresis and mannitol diuresis resulted in almost complete flow dependence of $\mathrm{U}_{\mathrm{Na}} \mathrm{V}$ with a relatively high floor for $\mathrm{U}_{\mathrm{Na}}$, as compared with water diuresis alone. Two illustrative experiments are plotted in Figure 8. During water diuresis alone the two normal subjects reached a floor for $U_{\mathrm{Na}}$ of about 1 to $2 \mathrm{mEq}$ per $\mathrm{L}$ at a flow of about $2 \mathrm{ml}$ per minute. Further increases in urine flow elicit proportionate increases in $\mathrm{U}_{\mathrm{Na}} \mathrm{V}$. During mannitol plus water diuresis the floor for $\mathrm{U}_{\mathrm{Na}}$ was about 8 to $10 \mathrm{mEq}$ per $\mathrm{L}$ at flows of about $4 \mathrm{ml}$ per minute, at which point $\mathrm{U}_{\mathrm{Na}} \mathrm{V}$ became almost completely flow dependent. The effect of water diuresis superimposed on solute (mannitol) diuresis is exactly the same as water diuresis alone in the sense that a floor for $U_{\mathrm{Na}}$ is quickly reached beyond which further increases in urine flow result in proportionate increases in $\mathrm{U}_{\mathrm{Na}} \mathrm{V}$. The only difference is that if there is a background of solute diuresis, the limiting concentration of $U_{\mathrm{Na}}$ during water diuresis is elevated.

\section{Discussion}

The present studies demonstrate that during rigid sodium deprivation, most patients with chronic renal disease are incapable of achieving sodium balance. Eleven of 14 of our patients showed mild but unrelenting sodium wastage when placed on dietary salt restriction. Two features characterize this sodium wastage: first, minimal $\mathrm{U}_{\mathrm{Na}}$ achieved by these patients is high (ranging from 9 to $27 \mathrm{mEq}$ per L), resulting in persistent

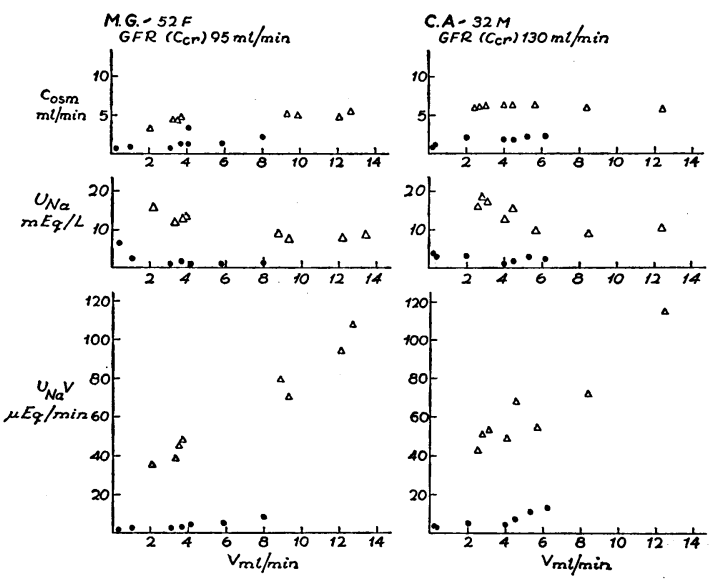

Fig. 8. The effect of a sustained, constant osMOTIC (MANNITOL) DIURESIS ON THE RELATION OF URINARY SODIUM TO URINE FLOW IN TWO NORMAL SUBJECTS DURING SALT DEPRIVATION. $=$ water diuresis alone; $\triangle=$ water diuresis superimposed on a constant mannitol diuresis. During water diuresis alone or superimposed on mannitol diuresis complete flow dependence of $\mathrm{U}_{\mathrm{Na}} \mathrm{V}$ was present. The effect of osmotic diuresis was to raise the minimal level of $U_{\mathrm{Na}}$ from about 1 to $2 \mathrm{mEq}$ per $\mathrm{L}$ to 9 to $10 \mathrm{mEq}$ per $\mathrm{L}$. The constancy of osmolar clearance $\left(\mathrm{C}_{\text {osm }}\right)$ is evidence that increasing $\mathrm{U}_{\mathrm{Na}} \mathrm{V}$ was not the result of increasing mannitol diuresis. 
sodium loss even at modest urine volumes of 1,000 to $1,500 \mathrm{ml}$ per day; second, the sodium wastage is aggravated by water diuresis. $\mathrm{U}_{\mathrm{Na}} \mathrm{V}$ increased proportionately with urine flow (Figure 4).

The presence of salt wastage in chronic renal disease might be explained as an inability of the distal nephron to increase its sodium reabsorptive capacity proportionate to an increase in sodium delivery out of the proximal nephron. Plentiful evidence exists that in renal failure the surviving nephrons are overperfused. Platt (3) and Bricker and associates $(15,16)$ have advanced evidence for the role of increased GFR and solute load (principally urea) per nephron. In addition, depression of proximal tubular reabsorption, as evidenced by the excretion of almost $25 \%$ of the filtered sodium (3), also contributes to overperfusion of the distal nephron. If the capacity for sodium reabsorption in the distal nephron failed to keep pace with the augmented delivery, a high minimal urinary sodium concentration would result.

However, this formulation fails to explain the second feature that characterizes renal salt wasting : flow dependence of sodium excretion during water diuresis should not occur if distal reabsorption were limited by partial saturation of the transport system secondary to increased sodium load. For example, in the normal subjects receiving high salt intake distal reabsorption is incomplete, not because $U_{\mathrm{Na}}$ was depressed to a limiting floor, but rather because distal reabsorption is partially saturated. Under these circumstances, when flow is increased in water diuresis, $\mathrm{U}_{\mathrm{Na}} \mathrm{V}$ remains constant and $U_{\mathrm{Na}}$ falls inversely to flow. Similarly, if the salt wastage in renal disease were due solely to partial saturation of distal reabsorption, it would be anticipated that $\mathrm{U}_{\mathrm{Na}} \mathrm{V}$ would be independent of urine flow and that $U_{\mathrm{Na}}$ would fall as flow mounted. We therefore conclude that salt wastage in chronic renal disease results, not from a limited ability to reabsorb sodium in the face of increased sodium loads, but rather from the inability to lower $U_{\mathrm{Na}}$ below a fixed relatively high value. ${ }^{2}$

2 Clapp, Watson, and Berliner (17) have demonstrated that the massive water loads required to induce water diuresis in the anesthetized dog undergoing micropuncture will suppress proximal reabsorption, presumably by expanding effective extracellular volume. The comparatively small amount of water administered in our studies ( $1 \mathrm{~L}$ by mouth in 30 minutes) would expand extracellu-
Once this fixed value is obtained during water diuresis $\mathrm{U}_{\mathrm{Na}} \mathrm{V}$ becomes completely flow dependent.

The flow dependence of $U_{\mathrm{Na}} \mathrm{V}$ is not unique to renal failure. Normal subjects on a salt-free diet exhibit complete flow dependence when $U_{\mathrm{Na}}$ is depressed to very low values during water diuresis (Figure 7). This characteristic of both normal individuals and patients with renal failure can be regularly demonstrated only during rigid salt restriction. If there is access to plentiful dietary salt, $\mathrm{U}_{\mathrm{Na}}$ starts at such a high level that increasing flow during water diuresis will not depress $U_{\mathrm{Na}}$ to its floor. In consequence $\mathrm{U}_{\mathrm{Na}} \mathrm{V}$ is only partially flow dependent in renal failure and independent of flow in normal subjects.

The difference between patients with renal failure and normal individuals is not the presence or absence of flow dependence, but rather the level of $U_{\mathrm{Na}}$ at which flow dependence commences. This value is about $10 \mathrm{mEq}$ per $\mathrm{L}$ in patients with renal disease (Figure 4) and $1 \mathrm{mEq}$ per $\mathrm{L}$ in normal subjects. At least three possible mechanisms might account for the higher $\mathrm{U}_{\mathrm{Na}}$ in the patients with chronic renal disease: 1 ) defective secretion of aldosterone, 2) tubular damage, and 3) increased osmotic load per nephron.

Since there is evidence that aldosterone enhances the reabsorption of sodium against concentration gradients in the distal nephron (18), and since the increased secretion of aldosterone in salt depletion is dependent on an intact juxtaglomerular system (19), it is conceivable that with extensive renal damage the gradient limitation is due to hypoaldosteronism. This possibility is excluded because the administration of large doses of $9 \alpha$-fluorohydrocortisone failed to lower $\mathrm{U}_{\mathrm{Na}} \mathrm{V}$ in balance studies on 3 patients during salt deprivation. In addition, in 4 patients studied before and after $9 \alpha$-fluorohydrocortisone, essentially the same $\mathrm{U}_{\mathrm{Na}}$ was observed during water diuresis (Table II). The second possibility is that, owing to tubular damage, the distal nephron is incapable of generating normal maximal concentration gradients. Several pieces of evidence, however, militate against this possibility and point towards increased

lar volume only minimally, and consequently would exert little inhibitory influence on proximal reabsorption. We believe, therefore, that the principal effect of water diuresis in these studies is not to augment sodium delivery to the distal nephron, but rather to increase distal flow rate. 
osmotic load per nephron as the cause of the apparent gradient limitation. The fact that lowering GFR by drug-induced hypotension resulted in a modest fall in $U_{\mathrm{Na}}$ indicates that when the osmotic load is decreased, the distal tubule has the ability to lower urine concentration below the apparent limiting floor (Table III). The most important evidence identifying increased osmotic load per nephron as the factor responsible for the high minimal $U_{\mathrm{Na}}$ is the fact that when osmotic diuresis was induced in normal salt-depleted subjects, a superimposed water diuresis resulted in marked changes in urine flow, a relatively high fixed $\mathrm{U}_{\mathrm{Na}}$, and flow-dependent $\mathrm{U}_{\mathrm{Na}} \mathrm{V}$ (Figure 8). Thus, it was possible by osmotic diuresis to mimic completely the defect in sodium excretion observed in the patients with severe renal insufficiency.

The foregoing analysis cannot necessarily be extrapolated to the massive salt-wasting syndromes in rare patients with renal disease (8-13). In these instances the delivery of sodium to the distal nephron may be so great that the reabsorptive capacity is exceeded. Even here partial flow dependence during water diuresis might be anticipated because the extreme solute diuresis would be expected to raise the minimal $U_{\mathrm{Na}}$ to comparatively high values. In the present study of the mild salt-wasting syndrome, the role of osmotic diuresis was to raise the level of the limiting $\mathrm{Na}$ concentration gradient without exceeding the reabsorptive capacity. It should be emphasized that flow dependence of $\mathrm{U}_{\mathrm{Na}} \mathrm{V}$ is not a unique feature of renal disease, since even normal subjects have a limiting value below which $\mathrm{U}_{\mathrm{Na}}$ cannot be depressed, and at which flow dependence of $\mathrm{U}_{\mathrm{Na}} \mathrm{V}$ appears. The effect of osmotic diuresis is not to produce the phenomenon of flow dependence but rather to determine the level of $\mathrm{U}_{\mathrm{Na}}$ at which flow dependence commences.

The present study re-emphasized that rigid restriction of dietary salt in nonedematous patients with chronic renal disease is hazardous. The stimulus to sodium reabsorption cannot maximally reduce $U_{\mathrm{Na}}$, so that even when urine volumes are only 1 to $1 \frac{1}{2} \mathrm{~L}$ a day, salt wastage develops. If water is forced, usually in an attempt to lower the blood urea concentration, the latter may indeed fall transiently, but salt wastage will be aggravated. Despite the salt wastage, body weight may not fall, or may fall only slightly, because water is retained as salt is wasted. The resulting hyponatremia is not a dilution hyponatremia in the sense that an expansion of total body water will dilute normal body stores of sodium but is rather the simple consequence of extensive salt loss while total body water is normal or even reduced. In consequence, treatment requires not merely water restriction, but the administration of salt. This need only consist of the addition of salt to the diet, since the re-expansion of extracellular volume will facilitate the more appropriate regulation of water excretion. For these reasons, the rigid restriction of dietary salt in severe renal disease, in the absence of salt retention, is a potentially dangerous procedure that requires close clinical scrutiny. On the other hand, if restriction of dietary salt is considered necessary for the treatment of hypertension, the provision of about 2 to $3 \mathrm{~g}$ of sodium chloride in the diet will suffice to maintain sodium balance in most patients.

\section{Summary}

The mechanism of salt wastage was studied in 17 patients with chronic renal disease. Persistent salt wastage could be demonstrated during rigid salt restriction in 10 of 14 patients during a 2- to 3 -week metabolic balance. The minimal urinary sodium concentration that could be elaborated during salt wastage was relatively high, ranging from 7 to $27 \mathrm{mEq}$ per L. Water diuresis increased urine flow without changing urinary sodium concentration so that sodium excretion rose in direct proportion to urine flow. The cause of the salt wastage was, therefore, attributed to the failure of the patients with chronic renal disease to reduce the urinary sodium concentration below a relatively high fixed value.

Normal subjects during water diuresis and salt deprivation also exhibited complete flow dependence for sodium excretion, but at very low concentrations of urinary sodium. Mannitol diuresis in these subjects elevated the concentration of urinary sodium at which flow dependence commenced. Flow dependence of urinary sodium excretion, therefore, is a characteristic of the normal as well as the diseased kidney. Osmotic diuresis raises the minimal urinary sodium concentration at which flow dependence commences. 
It is suggested that the higher concentration of urinary sodium at which flow dependence commences in chronic renal disease is a consequence of osmotic diuresis through the distal nephron.

\section{References}

1. Peters, J. P., A. M. Wakeman, and C. Lee. Total acid-base equilibrium of plasma in health and disease. XI. Hypochloremia and total salt deficiency in nephritis. J. clin. Invest. 1929, 6, 551.

2. Bradley, S. E. Biochemical abnormalities during renal insufficiency. New Engl. J. Med. 1946, 235, 755.

3. Platt, R. Sodium and potassium excretion in chronic renal failure. Clin. Sci. 1950, 9, 367.

4. Nickel, J. F., P. B. Lowrance, E. Leifer, and S. E. Bradley. Renal function, electrolyte excretion and body fluids in patients with chronic renal insufficiency before and after sodium deprivation. $\mathrm{J}$. clin. Invest. 1953, 32, 68.

5. Adams, D. A., C. R. Kleeman, L. H. Bernstein, and M. H. Maxwell. An evaluation of maximal water diuresis in chronic renal disease. II. Effect of variations in sodium intake and excretion. J. Lab. clin. Med. 1961, 58, 185.

6. Landis, E. M., K. A. Elsom, P. A. Bott, and E. Shiels. Observations on sodium chloride restriction and urea clearance in renal insufficiency. $\mathrm{J}$. clin. Invest. 1935, 14, 525.

7. Levin, D. M., and R. Cade. Influence of dietary sodium on renal function in patients with chronic renal disease. Ann. intern. Med. 1965, 62, 231.

8. Thorn, G. W., G. F. Koepf, and M. Clinton, Jr. Renal failure simulating adrenocortical insufficiency. New Engl. J. Med. 1944, 231, 76.

9. Murphy, R. V., E. W. Coffman, B. H. Pringle, and L. T. Iseri. Studies of sodium and potassium me- tabolism in salt-losing nephritis. Arch. intern. Med. 1952, 90, 750.

10. Levere, A. H., and L. G. Wesson, Jr. Salt-losing nephritis. Review and report of a case. New Engl. J. Med. 1956, 255, 373.

11. Knowles, H. C., Jr., H. Levitin, and A. Bridges. Salt-losing nephritis with fixed urinary composition. Amer. J. Med. 1957, 22, 158.

12. Stanbury, S. W., and R. F. Mahler. Salt-wasting renal disease. Metabolic observations on a patient with "salt-losing nephritis." Quart. J. Med. 1959, 28, 425.

13. Strauss, M. B. Clinical and pathological aspects of cystic disease of the renal medulla. An analysis of eighteen cases. Ann. intern. Med. 1962, 57, 373.

14. Giebisch, G., and E. E. Windhager. Renal tubular transfer of sodium, chloride and potassium. Amer. J. Med. 1964, 36, 643.

15. Bricker, N. S., P. A. F. Morrin, and S. W. Kime, Jr. The pathologic physiology of chronic Bright's disease. An exposition of the "intact nephron hypothesis." Amer. J. Med. 1960, 28, 77.

16. Bricker, N. S., S. Klahr, and R. E. Rieselbach. The functional adaptation of the diseased kidney. I. Glomerular filtration rate. J. clin. Invest. 1964, 43, 1915.

17. Clapp, J. R., J. F. Watson, and R. W. Berliner. Osmolality, bicarbonate concentration, and water reabsorption in proximal tubule of the dog nephron. Amer. J. Physiol. 1963, 205, 273.

18. Vander, A. J., W. S. Wilde, and R. L. Malvin. Stopflow analysis of aldosterone and steroidal antagonist SC-8109 on renal tubular sodium transport kinetics. Proc. Soc. exp. Biol. (N. Y.) 1960, 103, 525.

19. Davis, J. O. The control of aldosterone secretion. Physiologist 1962, 5, 65. 